\title{
How should agriculture produce enough food for the world?
}

\begin{abstract}
Author:
Petrus Simons ${ }^{1}$

Affiliation:

${ }^{1}$ School for Basic Sciences, North-West University,

Vaal-Triangle Campus,

South Africa

Correspondence to:

Petrus Simons

Postal address:

PO Box 12-294, Wellington

6144, New Zealand

Email:

petrus.simons@xtra.co.nz

Dates:

Received: 27 Mar. 2012

Accepted: 03 Oct. 2012

Published: 14 Dec. 2012

How to cite this article:

Simons, P., 2012, 'How

should agriculture produce

enough food for the world?',

Koers - Bulletin for Christian

Scholarship 77(2), Art. \#431,

8 pages. http://dx.doi.org/

10.4102/koers.v77i2.431
\end{abstract}

C 2012. The Authors

Licensee: AOSIS

OpenJournals. This work

is licensed under the

Creative Commons

Attribution License.
From an agricultural point of view, the question if the earth can feed adequately not only its current population of 7 billion people, but also the expected population of 9 billion people to 10 billion people by 2050, is currently answered in two opposing ways. Some believe modern agriculture should increase productivity by implementing technological innovation and eliminating subsistence agriculture. Others believe industrialised agriculture is out of tune with the ecology and sufficient healthy food may be produced by an agriculture that recognises ecological and biological limits (known as ecological intensification). On the basis of a theoretical framework derived from reformational philosophy and in particular the concept of enkapsis, this article supports ecological intensification, especially if it forms part of a cultural development guided by Schuurman's metaphor of a garden-city. However, it is still a marginal activity within a culture directed by a belief in progress. High rates of economic growth, based on technological innovation, appears to validate such faith, but human and environmental costs are insufficiently acknowledged (metaphor: the earth is a machine). A break with technicism and economism becomes a pre-condition for feeding adequately both the present and the projected population of the world.

Hoe kan die landboubedryf genoeg voedsel vir die wêreld produseer? Die vraag of die aarde in staat is om nie net die huidige populasie van 7 biljoen mense nie, maar'n geskatte 9 biljoen mense tot 10 biljoen mense teen 2050, voldoende te voed, word tans op twee verskillende maniere beantwoord. Daar is diegene wat glo dat moderne landbou produktiwiteit moet verhoog deur deur tegnologiese vernuwing, terwyl bestaansboerdery geëlimineer moet word. Hierdie oplossing word teengestaan deur diegene wat glo dat geïndustrialiseerde landbou nie in pas is met die ekologie waarin dit plaasvind nie. Hulle redeneer dat daar steeds genoegsame produksie van gesonde voedsel kan wees wanneer ekologiese en biologiese grense in ag geneem word (ekologiese intensivering). In die lig van 'n teoretiese raamwerk wat ' $n$ oorsprong in die reformatoriese filosofie het, en in besonder die enkapsis-konsep, is daar in hierdie artikel geredeneer dat ekologiese intensivering die beter alternatief is, veral wanneer dit deel uitmaak van 'n kulturele ontwikkeling gelei deur Schuurman se tuinstadmetafoor. Dit is egter steeds ' $n$ marginale gedagte in ' $n$ kultuur wat oorheers word deur die geloof in vooruitgang. Sodanige geloof word skynbaar geregverdig deur die hoë ekonomiese groeikoers wat op tegnologiese vernuwing gebaseer is, maar, alhoewel dit nie genoegsaam erken word nie, geskied dit ten koste van die mens en die omgewing (metafoor: die aarde is 'n masjien). 'n Breek met tegnisisme en ekonomisme word 'n voorwaarde vir voldoende voedsel vir die huidige sowel as toekomstige wêreldbevolking.

\section{Introduction}

The world's population was estimated to be beyond 7 billion people by the end of March 2012 . Therefore it becomes important to ask if the earth can provide sufficient food for all these people, and for the 9 billion people or 10 billion people expected by 2050 and beyond. According to data published by the Food and Agriculture Organization (FAO), about 1 billion people already do not have enough to eat (Ziegler 2011). Two opposing answers are given:

1. Industrial agriculture should be raised and subsistence farming modernised to increase productivity.

2. Industrial agriculture has been wrongly directed, especially by ignoring its environmental consequences and should be replaced by ecological (also known as biological or organic) agriculture to increase production. (p. 24)

These answers spring from two different worldviews. The first answer is associated with an ideology of technological progress, reflected in economic growth. The second answer opposes the first, denouncing especially adverse effects on animal welfare and the environment, and believes that sustainable agriculture should acknowledge ecological limits. 
In order to flesh out these differences a theoretical framework is set up, derived from H. Dooyeweerd's (1894-1977) reformational philosophy, especially his concept of enkapsis. The view of agriculture as an enkapsis, encompasses three approaches to farming, namely industrial, traditional and biological or ecological.

The controversy between industrial and ecological agriculture arises from a dialectic between a culture that seeks an ordering of society by scientific technology and economics, represented by the metaphor of the earth as a machine (Descartes) and one that oppose its consequences, but might foster other absolutisations. Our technological culture is very destructive. Bio-diversity, which is of vital importance to a sustainable agriculture, is dwindling away and soils are being degraded. Hence, to ensure that the current and future populations of the world have sufficient food, technicism and economism should be relinquished. Unless this happens, ecological agriculture remains a marginal activity, unable to fully realise its potential. Under the same proviso, and guided by the metaphor of the earth becoming a gardencity (Schuurman), industrial agriculture may be transformed gradually to become ecologically acceptable.

\section{A theoretical framework}

A theoretical framework is called for to understand the nature of and problems experienced by agriculture. Reformational philosophy as developed by H. Dooyeweerd (1894-1977), D.H.Th. Vollenhoven (1892-1978) and H. Stoker (1899-1993) and their followers provide the building blocks.

\section{Structure}

The creation answers to a structure or building plan, which may be approached in the idea. As such, it presents itself in three dimensions or moments: temporal, individual and modal (Popma 1956:9-15).

Structure makes reality possible. We encounter individual subjects who come into being and after a longer or shorter period of time die or disappear (time as lifeline). Individual subjects are grouped, in order of increasing complexity (Vollenhoven 2005b:97-100), into the kingdoms of minerals, bacteria, plants, animals and people (Klapwijk 2009:16). The subjects of a kingdom are not interchangeable with those of other kingdoms. People marry people, not animals. Individual subjects are 'so or so,' indicated by nouns.

Kingdoms develop according to particular pathways, known as modalities or ways of being, usually indicated by adverbs or 'this way or that way'. There are 15 modalities, arranged from the numerical to the pistical (number, space, kinetic, energetic, organic, psychic, analytical, technical, lingual, social, economic, aesthetic, juridical, ethical, pistical) and analogically inter-related through anticipations and retrocipations. Time is present in modalities as cycles or rhythms.

Subjects function in time, according to the modalities. A subject of one kingdom may play a role, as object, in a higher kingdom. Animals drink water, eat plants, and use bacteria to digest their food. These are object functions.

Dooyeweerd (1969, volume III:627-732) has advanced the concept of enkapsis to indicate that many individual subjects encompass subjects from other kingdoms in their structure such that the latter retain their original properties, but also show the imprint of their host. A bird's nest is made from twigs arranged so as to serve the fledglings. The bird does not change the twigs, but fashions them into a nest. An enkapsis is indeed 'an interwovenness of individuality-structures (Dooyeweerd 1969, volume III:636).

\section{The enkapses of agriculture}

Plants and animals are structures in their own rights. When they are incorporated into a farm, they remain plants and animals. However, they also change as farmers start propagating and breeding them to produce food and other materials. Since a farm depends on the availability of plants and animals, the enkapsis is foundational (Dooyeweerd 1969, volume III:652).

Analysing farming as an enkapsis, Dooyeweerd (1969) notes:

1. The fields, pastures, cattle, buildings (with their stockin-trade) function in this human societal structure, as well as all the usable objects belonging to the farming. The land and the cattle are qualified only as economic objects of the latter as far as their enkaptic function is concerned.

2. But the animals functioning as the live-stock of the farm are, as such, that is, in their own internal structure, certainly not of a typically economic qualification. They are natural beings, according to their inner animal nature bound to the pasture (as a vegetative collectivity) in a symbiotic interlacement, and interwoven in a correlative enkapsis with their Umwelt [environment]. They live in an animal bi-unity when they copulate, and for some time after the birth of the young, at least the mother lives in a natural community with the latter.

3. In this enkapsis industrialised natural things display cultural-economic variability types. The businessorganization, binding animals, pastures and fields in their natural structure, is interwoven with a great number of other human societal structures; also the industrial objects are included in these new, extremely complicated enkaptic relations (volume III:652).

Quote 1 suggests that a farm is an economically qualified entity (modal point of view). A farm is set up to produce food as well as materials for industrial purposes, for distribution at prices or rewards that allow the farm to continue functioning. In order to carry out this economic function, farmers will use plants and animals only to the extent they are able to serve the farm's economic function.

Quote 2 strengthens the point of quote 1 and, using a dairy farm as example, states that cows have a symbiotic relationship with pastures. Clearly, cows must eat grass, 
whilst cow pats fertilise grassland. Farmers must attend to the natural needs of their herds.

Quote 3 extends the point of quote 2 by stating that the farm itself will be embedded in a rich variety of relationships in which it will remain a distinct entity, albeit interdependent with, for instance, a dairy co-operative or a farm extension service.

In a broader sense, Dooyeweerd's theory of enkapsis enables us to view farming in relation to its place within ecosystems. In general, however, he does not pay much attention to the management of enkapses, in spite of the fact that he often points to the dynamic unfolding of the creation, and the calling of humankind to be its responsible stewards. In reformational philosophy, this issue is dealt with in terms of human functions and their direction towards good or evil.

In order to explore the question of how the current and the expected future population of the world might be fed properly, the practical management of the enkapses must be emphasised. Firstly, a brief historic overview will be given of the three ways of management used hitherto. Secondly, answers by defenders of industrial and ecological agriculture will be referred to, followed, thirdly, by a suggestion for possible future development.

\section{Managing the enkapses}

Agriculture was invented about 10000 years ago, when the human population was about 2 million people. Prior to that people were hunters and gatherers. Given that homo sapiens are about 200000 years old, agriculture is a relatively recent activity. Nevertheless, it has enabled a veritable population explosion to the present 7 billion people over about 350 generations (Wells 2010:15). So, how did farmers do it? Broadly, they have been using three methods:

1. trial and error in traditional agriculture

2. application of scientific or technological methods to exploit nature (industrial agriculture)

3. an ecological method with scientific or technical input in what is known as organic or biological farming (to be referred to as ecological agriculture hereafter).

\section{Traditional agriculture}

The trial and error period of farming along with the formation of good practice traditions lasted, broadly speaking, until the beginning of the Industrial Revolution in the 18th century in Western countries. In most non-Western countries, by contrast, traditional farming (subsistence farming), still prevails. Traditional farmers have often developed highly productive and long-lasting farming systems by working with nature (Dufumier 2004).

Traditional farms have tended to be family based. The harvests cover the needs of the farmer and his or her family and/or may be sold to others or bartered from others in local communities in exchange for supplies. Such farms are usually small scale, but there are also cases of large scale operations, such as the latifundia in the Roman Empire, and large farms growing cereals in Europe. Typically, they became part of trading systems and anticipated in this way current industrial farming systems.

Trial and error methods have not prevented major mistakes such that whole civilisations have perished (Carter \& Dale 1974). Often, a long-term neglect of soil was to blame. This is not too surprising, since good soil is formed over very long periods of time, whilst injudicious agricultural practices may waste or mismanage it imperceptibly. Amazingly, traditional agriculture has used no more than three species of plants that constitute the staff of life: rice, maize and grains, albeit with a prolific number of varieties.

\section{Industrial agriculture}

The development of organic chemistry (by, amongst others, Justus von Liebig [1803-1870]), which was at the basis of nitrogen, potassium and phosphate as a universal mix of fertilisers; the discovery of the laws of inheritance by Mendel (1822-1884), which led to the use of hybrids (from two inbred or genetically uniform lines); and the manufacturing of nitrogen fertiliser (by means of gas by the Haber-Bosch method) have transformed agriculture into an industrial activity guided by science. To this should be added the use of hydro-carbons not only as a transport fuel but also as a source of farm inputs such as fertilisers and some pesticides. Often, public research institutions are set up to develop new fertilisers, establish new varieties, and breed more productive animals.

The introduction of rapid transport and mechanical farm implements since the middle of the 19th century led to the development of large-scale farms in areas colonised by Western powers in the Americas, India, Australia, and Russia. In other countries mechanisation was introduced only after the Second World War. This has led to world markets for agricultural inputs and outputs. For individual farmers who produce an infinitesimal proportion of the world's supply, this provides an incentive to increase their production to benefit from given prices. Given that most of their costs are fixed, this means that their unit costs fall. When all do this, however, supply exceeds demand and prices fall, leading to another attempt to raise productivity. This phenomenon is known as the treadmill (discussed by Hathaway 1963:107-130). It explains why farmers are keen to buy new implements and supplies even when their income is down.

Soule and Piper (1992) argue that industrial methods are reductionist since they resolve one problem at a time, for example, a lack of nitrogen is overcome by applying more nitrogen, even when this might result in nitrate pollution of soil and water. They argue, correctly, that this methodology is the legacy of René Descartes (1596-1650) and that its strong point is the identification of critical factors 'that have a strong influence on a system'. However, 'it opens us to the danger of missing a great deal of the functioning of complex systems, such as agro ecosystems' (Soule \& Piper 1992:72). 
TABLE 1: Modern agricultural practices that have contributed to the current ecological and economic crises.

\begin{tabular}{ll}
\hline Practice & Problems created \\
\hline Mechanisation & $\begin{array}{l}\text { Erosion, energy dependency, larger farms, less farmers, } \\
\text { financial problems }\end{array}$ \\
$\begin{array}{l}\text { Inorganic nitrogenous } \\
\text { fertiliser }\end{array}$ & $\begin{array}{l}\text { Groundwater contamination, farm specialisation, pests, } \\
\text { erosion, energy dependency, high input expenses }\end{array}$ \\
Pesticides & $\begin{array}{l}\text { New pests, resistant pests, water pollution, human } \\
\text { poisoning, energy dependency, high input expenses }\end{array}$ \\
$\begin{array}{l}\text { Hybrids and genetically } \\
\text { narrow varieties }\end{array}$ & $\begin{array}{l}\text { Aggravated pest problems, loss of local adaptations, } \\
\text { chemical dependency, high input expenses }\end{array}$ \\
\hline
\end{tabular}

Source: Soule J.D. \& Piper, J.K, 1952, Farming in nature's image; An ecological approach to agriculture, Island Press, Washington D.C.

Soule and Piper outline the problems caused by modern agriculture as follows (1992:52, with some slight modifications) (See Table 1).

Soule and Piper published this work before the advent of genetic engineering and the death of billions of bees (Colony Collapse Disorder). Remarkably, they fail to mention the massive use of antibiotics to promote the growth of farm animals, with the associated problem of resistance. Each of these developments would have deepened their concerns.

The table should be extended by emphasising that the life-lines of farm animals are quite short, because they are slaughtered as soon as they cease to be productive or have become ripe for processing (such as lambs). Mating is being dispensed with as procreation since artificial insemination is more efficient.

In terms of Dooyeweerd's theory of enkapsis it can be said that modern large-scale industrial agriculture has become founded on scientific technology. When farmers need to milk 400 cows or more a day, they should have a rotary shed, vats, and access to electric power. Technical failures would cause considerable damage and distress. Tudge (2003:257) extrapolated current trends by suggesting that 'over the next few centuries it would surely be possible to create, say, a cow that was reduced entirely to an udder (which could be fed artificially)' . It would be a completely technicised cow.

So, instead of farmers being reliant on their domesticated plants and animals, they and their animals and plants are more and more dependent on science and technology, especially if we take the whole chain of supply and processing into consideration. This is a reversed foundational enkapsis. Tudge (2003) argues that:

industrial farming is not sustainable because it is not designed to be: 'the role of science in this new, industrialized agriculture is not to abet good husbandry, but to override it'. (p. 277)

An anecdote may underline this point. In 1894, Marcellin Berthelot, a (chemistry) scientist saw a golden age by 2000 in which all agriculture had disappeared because people would be fed by chemical pills manufactured economically in inexhaustible quantities (Testart et al. 2010:126).

\section{The link between industrial agriculture and economic growth}

The reverse foundational enkapsis of industrial agriculture contributes significantly to economic growth through the production of goods and services required by farmers and the processing and distribution of their produce. If farms used their own seeds, as they used to do for centuries, and produced their own fertiliser, the rate of economic growth would decline.

The pursuit of economic growth has been accentuated in recent years by the switch from producing food to growing crops of maize, wheat, and sugar for transformation into ethanol as a substitute for crude oil, of which the most easily accessible reserves are declining. In Australia Chinese demand for coal has led to an expansion of mining at the expense of fertile farmland (Sprothen 2012:21).

In Asia and Latin-America a rapidly increasing number of people enjoy incomes that allow them to buy protein-rich food such as meat and dairy products. Therefore the demand for land to produce meat and feed for cattle, pigs and poultry will be rising, resulting in a significant felling of tropical forests (Reichholf 2006), a major loss of bio-diversity and increasing emissions of greenhouse gases such as carbon dioxide and methane (by cattle and sheep).

Market intervention systems to stabilise prices in North America and Europe have enabled farmers to increase profits through higher productivity and and reduced unit costs, thereby creating surpluses which have been dumped on world markets, often at subsidised prices and to the detriment of local subsistence farmers. The latter have been forced to abandon their farms and migrate to urban areas, where they form a cheap labour force for large international business corporations. Only slow progress has been made in outlawing subsidised exports of surplus produce.

\section{Ecological agriculture}

In contrast to industrialised agriculture, ecological agriculture seeks to maintain and even intensify its original foundational enkapsis. Land and water are not seen as inputs for production and making profits, but rather as complex realities without which life is impossible.

Pérez-Vitoria (2010) notes that subsistence agriculture does not regard land as capital but rather as the locus of a way of living, often held in common by a local community. Implied in this is the idea that working the land is a communal activity for the common good. Remuneration is often in kind. Human labour should not to be replaced by machines.

Importantly, nature is seen as producing gratuitously: 'every eco-system presents its own properties, with human labour taking advantage of them across time and space' (PérezVitoria 2010:114). Agricultural practice should ensure that nature maintains its capacity to yield its fruits gratuitously, for example by ensuring that micro-organisms in the soil are not killed by chemical fertilisers:

The idea of substituting commercial values for the free gifts of nature is foundational to agricultural modernisation. Agricultural research has worked hard to find the means of bypassing or replacing nature, commercialising in passing many 
of its functions. Hydroponics enables not only an escape from the climate by substituting artificial heat for sunshine, but also by substituting chemicals for the organic life of the soil. (PérezVitoria 2010:116 [translated by author])

In temperate climates, the ideal has been to mix livestock and plants, so that they can feed on each other. There is a rich variety of such systems around the world. In Laos, for instance, between 3000 and 4000 varieties of rice are sown on $80 \%$ of cultivated land (Pérez-Vitoria 2010:118). A key tenet of this movement is that people should be able to grow their own food, with trading limited to residual surpluses and deficits.

In general, key features of ecological agriculture are opposite to those of industrial agriculture:

1. small scale, often run by families

2. mixed farming (livestock plus cereals etc.)

3. traditional knowledge

4. organic fertilisation

5. biological pest control (no chemical pesticides)

6. no genetic engineering (GE)

7. high standards of animal welfare.

Genetic Engineering is defined as a transgenic modification whereby a gene or fragment of a gene is implanted in a gene sequence of a completely different organism. It is a very artificial enkapsis, assuming that a gene or a fragment thereof may be regarded as an individuality structure. Some GE food crops contain alien gene fragments that cause the plant to manufacture its own insecticides. The long-term effects on humans and the environment are unknown. Another problem is that pollen from GE plants may travel to wild plants, so that it becomes more difficult to refresh the gene pool of agriculture. For these reasons, GE does not fit in with ecological agriculture.

\section{Ecological intensification (agro-ecology)}

During the 1970s, a movement began in Latin-America which seeks to develop agriculture in an ecologically acceptable manner. The eco-system should be seen as a set of interdependencies between the environment and living species. Since traditional agriculture has generally been in tune with natural equilibria, a study of how it worked should be a good starting point (Pérez-Vitoria 2010:158-160) for new ecologically responsible forms of agriculture. The term agroecology or ecological intensification means, therefore, that ecosystems in which agriculture takes place should not only be preserved, but also improved rather than destroyed or degraded.

Löwenstein (2011) argues that ecological intensification sets priorities that differ from industrial agriculture, namely:

1. feeding the family properly

2. feeding the farm animals, because they represent the family's financial reserves

3. nurturing the soil, because it is foundational to growing crops

4. supplying the market only when the first three are taken care of. (p. 181)
He points out that agro-ecology or ecological intensification is not just industrial agriculture without chemicals. In one of the driest and poorest regions of Northern Ethiopia (Tigray) the Institute for Sustainable Development and the FAO examined 779 fields on which 14 different crops were grown between 2001 and 2006. Some were composted, others provided with phosphate and nitrogen chemical fertilisers and the rest were not fertilised at all. The yields of composted fields were far superior to the other two (Löwenstein 2011:192-195).

The Tigray region has been greened by means of relatively simple methods such as terracing and planting trees. Government policy requires villagers to give thirty days labour annually to the project: 'with only adzes, shovels, pickaxes, palm leaf brushes, or nothing at all they have transformed parts of this region without the world knowing anything about it' (Oxlade 2011:33-35). Such methods have enabled a greening so far of 50000 square kilometres in Niger and 10000 square kilometres in Ethiopia. The methods have been successful because they use the properties of the ecosystem responsibly.

Another example is the solution to the problem of the corn borer found by the International Centre of Insect Physiology and Ecology in Kenya along with the Rothamsted Research Institute in Britain. Farmers plant Desmodium between the maize. The leaves emit a smell which the borers cannot stand, causing them to depart. Moreover, Napier grass is planted around the plots to pull the borers out of the crops to lay their eggs in the grass. The caterpillars, however, cannot eat the grass and die (Löwenstein 2011:202-203).

Given the enormous stresses on agriculture in years to come, Parmentier advocates the substitution of natural supports for artificial ones to allow plants, bees, worms, ladybirds, bacteria, and fungi to produce what machines and chemistry produced. Two major cultures should join their efforts: agronomists, who want to decipher nature to produce more and ecologists, who want to understand nature without transforming it. They should communicate effectively with farmers. We should envisage a multi-diverse highly localised agriculture that is properly thought through. This is far better than setting targets such as using $x \%$ less pesticides by a certain date (Parmentier 2009:277-279).

\section{Is it possible to feed the world's growing population?}

The United Nations estimate that the world's population is likely to grow from the present 7 billion people to around 9 billion people or 10 billion people by 2050. This already huge challenge for agriculture to produce enough food, is even more daunting when account is taken of the 1 billion people who are severely and permanently under-nourished according to the FAO (Ziegler 2011:24), not to mention another 1 billion people suffering from silent hunger, having deficiencies in proteins and micro-nutrients such as iron, iodine and vitamin A (Ziegler 2011:49ff). 
Joachim von Braun (Director of the International Food Policy Research Institute in Washington from 2002-2010) believes that climate warming will increase the expected number of under-nourished children from an estimated 113 million children to 140 million children by 2050 . The problems to be addressed are:

1. provision of water

2. soil degradation (the skin of the earth has cancer)

3. herds of cattle as emitters of greenhouse gases

4. rice fields as they emit methane.

Von Braun suggests that science and scientific technology should be stimulated and financed to tackle these problems. GE is called for, not only to increase productivity to cope with a diminishing availability of land and water, but also to tackle silent hunger. Meanwhile, countries should coordinate their policies of forming stocks of key foods such as grain and rice. He opposes the sale of land and water used by small farmers, to money-rich countries such as China and Saudi-Arabia (Sentker 2010:31). One can detect in Von Braun's view the single factor approach, which Soule and Piper see as Descartes's legacy, especially in his view on GE.

An analysis of the Green Revolution of the 1960s and 1970s should inspire caution, however. It featured new high yielding varieties of grain, rice, with shorter straws, requiring high applications of chemical fertilisers, pesticides, and water. Although it raised production strongly, it forced small farmers to incur high debts to buy seeds, fertilisers, and pesticides. Many ceased farming, often by suicide (Martin $\&$ Kakde 2006). The new varieties have displaced many traditional varieties. Yields have started to decline under the impact of salination, caused by irrigation, and a growing resistance of insects and diseases to pesticides.

In contrast to advocates of industrial farming, those in favour of ecological agriculture plead for re-thinking agriculture and the provision of food. Local populations should enjoy food sovereignty. This goes well beyond self-sufficiency. As Pérez-Vitoria (2010:232) puts it: 'It must be carried locally by movements of farmers aware of their rights and duties with respect to nature as well as the population to be fed'. In general, those pleading for ecological agriculture believe that by preserving and enhancing traditional knowledge and practices the world's current and expected population can be fed adequately. This amounts to a careful husbandry within the limits posed by each particular ecological system. Due to being generally small-scale, ecological agriculture offers farmers the possibility of developing a caring relationship with their animals, plants, and soils.

\section{The controversy between industrial and ecological agriculture}

The differences between industrial and ecological agriculture are not merely theoretical. Despite the successes of ecological intensification, for instance, the FAO is adamant that it cannot feed the world's population. In this respect, it is joined by the International Monetary Fund (IMF), the World Bank, and the World Trade Organization (WTO). Behind these organisations and the US government are the powers of major agro-industrial companies who command large financial resources and have invested heavily in the production of chemicals and (genetically engineered) seeds and farm machinery. No more than 200 corporations specialising in agro-food production control $25 \%$ of the world's productive resources (Ziegler 2011:155-161). They insist that the problem of hunger must be overcome by industrialising agriculture, applying the latest technologies and eliminating inefficient subsistence or family agriculture (Ziegler 2011:162, 163), whilst all obstacles to international trade should be removed.

Proponents of ecological agriculture are equally convinced that the present high productivity of industrial agriculture is unsustainable, because it is based on a slow ecological destruction. Considering climate warming, declining areas of fertile land, over-exploitation of ground water, decreasing bio-diversity, and a growing demand for meat, food crises will occur more frequently.

The only hope is that the world would change course and adopt a programme of supporting small farmers on their own land, develop ecological intensification and help countries and people produce their own food, with trading limited to residuals, thereby eliminating waste (water, food, etc.). Many examples can be given of such an approach from the bottom up (Bommert 2009:322-326).

The world food conference held in June 2008 in Rome and called by the FAO had before it a report prepared by 400 experts: 'International Assessment of Agricultural Knowledge, Science, and Technology for Development'. However, the conference was strongly influenced by representatives of agro-business who managed to sideline the report's emphasis on small farmers as carriers of hope in the battle against poverty and hunger (Bommert 2009:305).

\section{Back to managing the original enkapsis}

In order to produce more healthy food for all, lessons can be learned from each of the three methods used to farm, provided one applies the criterion: how should agriculture recover the original, given, foundational enkapsis?

Only a few suggestions can be made. Governments at all levels and farming communities should:

1. Ensure that their populations are adequately fed.

2. Clean and preserve resources of water (streams, sea, water levels).

3. Map and restore soils and halt soil erosion and salination.

4. Cease nitrogen intensive ways of producing meat to reduce pollution of water and air, and improve animal welfare.

5. Discourage imports and exports of food by controlling domestic production.

6. Encourage research into new methods of biological (ecological) horti- and agriculture. 
7. Teach the unemployed in urban areas how to grow high quality vegetables, tend beehives, poultry et cetera on vacant land, including rooftops.

8. Conduct research aimed at phasing out pesticides and chemical fertilisers.

9. Preserve moisture and carbon in soil in dry areas by applying cross-slot seed drills (invented and developed by Dr John Baker of New Zealand) instead of ploughing.

10.Improve food security by reducing transport using fossil fuels to a minimum, not only to reduce emissions of greenhouse gases but also to minimise the allocation of fertile land to motorways and urban sprawl.

11.Reduce the cultivation and use of sugars, grains and so forth for drinks and alcohol.

In combination, such policies would improve food security for a growing world population. The chances of success of this approach are not very high, however, due to the deepseated ideology of materialism. The battle for different values should be waged by contrasting two metaphors.

\section{Two metaphors}

The spirit of our time features absolutisations of science and technology (technicism) and money (economism). It is a spirit that is embodied in the business plans of large business corporations. They develop new products and markets on the basis of science applied in new technologies. In order to safeguard their capital they engage in intense lobbying with governments, international organisations, and educational institutions.

Western and Westernised societies follow their self-made technicistic or economistic norm that what can be made or done should be made or done, especially if it appears to solve our problems and is financially feasible or profitable (Schuurman 2005). In terms of Vollenhoven's historiography of philosophy, the spirit of a time period concerns a struggle for the place of the law (Vollenhoven 2005a:109). This is true not only with regard to philosophy but also for society as a whole. The powers of business, education, and governmental institutions situate the place of the law of that which defines the core of and key to life in science and technology as sources of economic growth.

This spirit has its roots in the philosophy of Descartes, who believed that by studying and applying the laws of physics we would 'render ourselves the lords and possessors of nature' (Descartes 1953:49). Drawing a dualistic distinction between body and soul, he argued that, if we ignore the perceptions of the senses (which he saw as related to the soul), the earth is a machine (Descartes 1953:214). It is the metaphor of the earth as a machine that motivates the technicisation (application of technicism) of industrial agriculture.

The age of Enlightenment strengthened technicism through its ideal of progress. Adam Smith (1723-1790), for example, wondered about the causes of 'the slow progress of opulence' given the advantages of the division of labour (Smith 1978:521).
The latter is clearly related to the design of fast machines and the specialisation to which it gives rise. The industrial revolution became the means whereby science entered the world of business.

Since technicism is based on an absolutisation of technical control, freedom will suffer. The controversy highlighted above involves a dialectic between the scientific or technical or financial control of agriculture and small-scale ecological agriculture, which faces destruction by the former. It is a dialectic because the industrial powers will make some concessions to show that they are ecologically responsible, but without foregoing their control. The danger is that the reaction against this takes the form of making nature an absolute. There are forms of organic agriculture, inspired by vitalism, that appear to have fallen into this trap. It is for this reason that ecological agriculture, when understood as enhancing the given enkapses of agriculture, offers the best prospects not only for escaping from the dialectic, but also for feeding the world's present and future population.

The reason for this is that ecological (biological) agriculture comes close to the metaphor of culture as a gardencity, advocated by Schuurman (2005:37-39) in various publications. Gardens will be delightful when they do justice to all modes of being, not only the technical and economic, but also the aesthetic and ethical (animal welfare, for example) modes. Farmers who are now part of industrial agriculture could gradually change to an ecological approach, especially by working together.

\section{Conclusion}

The world's growing population cannot be fed properly if the modern Western patterns of production and consumption are seen as normative and are spread across the world. They would put an incredible pressure on natural resources such as bio-diversity, potable water, and fertile land. Climate warming would be intensified, resulting in a destruction of fertile farmland. Epidemics could easily arise and spread like wildfire across the world. Battles for control of scarce resources such as oil, water, and food could lead to armed conflicts. At the root of these problems is the spirit of technicism and economism, which sees the world as a machine.

If this spirit gives way to a different spirit, represented by the metaphor of a garden-city, a spirit of nurturing, modesty and caring for the weak, whilst avoiding and eliminating our wasteful ways, a basis would be laid for a world population of 9 billion people to 10 billion people that would be adequately fed, housed, and cared for.

\section{Acknowledgements Competing interests}

The author declares that he has no financial or personal relationships which may have inappropriately influenced him in writing this article. 


\section{References}

Bommert, W., 2009, Kein Brot für die Welt: Die Zukunft der Welternährung, Riemann, München.

Carter, V.G. \& Dale, T., [1955] 1974, Topsoil and civilization, University of Oklahoma Press, Norman.

Descartes, R.A., [1637] 1953, Discourse on method, J.M. Dent \& Sons, London.

Dooyeweerd, H., 1969, A new critique of theoretical thought, vol. III, Presbyterian and Reformed Publishing Company, Philadelphia.

Dufumier, M., 2004, Agricultures et paysanneries des Tiers mondes, Karthala, Paris.

Hathaway, D.E., 1963, Government and agriculture: Economic policy in a democratic society, Macmillan, New York.

Klapwijk, J., 2009, Heeft de evolutie een doel? Over schepping en emergente evolutie. J.H. Kok, Kampen.

Löwenstein, Z., 2011, Food crash: Wir werden uns ökologisch ernähren oder gar nicht mehr, Pattloch, München.

Martin, M. \& Kakde, S., 2006, From debt trap to death trap; victims of 'free' markets; an enquiry into farmers' suicide, Vikas Adhyayan Kendra, Mumbai.

Oxlade, L., 2011, 'Greening the Sahara', Permaculture 68, Summer, 33-35.

Parmentier, B., 2009, Nourrir l'humanité; Les grands problèmes de l'agriculture mondiale au XXI siècle, La Découverte, Paris.

Pérez-Vitoria, S., 2010, La riposte des paysans, Actes Sud, Arles.
Popma, K.J., 1956, Inleiding in de wijsbegeerte, J.H. Kok, Kampen.

Reichholf, J.H., 2006, Der Tanz um das goldene Kalb; der Ökokolonialismus Europas, Klaus Wagenbach, Berlin.

Schuurman, E., [2002] 2005, The technological world picture and an ethics of responsibility, Dordt College Press, Sioux Center.

Sentker, A., 2010, 'Brot allein macht nicht sat. Interview of Joachim von Braun', Die Zeit, Hamburg, 07 January, p. 31.

Smith, A., [1766] 1978, Lectures on jurisprudence, Oxford University Press, Oxford.

Soule J.D. \& Piper, J.K, 1992, Farming in nature's image; An ecological approach to agriculture, Island Press, Washington D.C.

Sprothen, V., 2012, 'Ein riesiges Minenloch', Die Zeit, Hamburg.

Testart, J., Sinaï, A. \& Bourgain, C., 2010, Labo Planète: ou comment 2030 se prepare sans les citoyens, Mille et Une Nuits, Paris.

Tudge, C., 2003, So shall we reap, Penguin, London.

Vollenhoven, D.H.T.h, 2005a, in K.A. Bril (ed.), The problem-historical method and the history of philosophy, De Zaak Haes, Amstelveen.

Vollenhoven, D.H.T.h, 2005b, Isagogè philosophiae; introduction to philosophy, Dordt College Press, Sioux Center.

Wells, S., 2010, Pandora's seed; Why the hunter-gatherer holds the key to our survival, Penguin, London.

Ziegler, J., 2011, Destruction massive; Géopolitique de la faim, Éditions du Seuil, Paris. 